ТЕОРЕТИЧНІ ТА ПРАКТИЧНІ АСПЕКТИ ВИКОРИСТАННЯ

ТАЙМ-МЕНЕДЖМЕНТУ У ПРОФЕСІЙНІЙ ПІДГОТОВЦІ МАЙБУТНІХ МОЛОДШИХ СПЕЦІАЛІСТІВ СЕСТРИНСЬКОЇ СПРАВИ В КОЛЕДЖАХ

\title{
THEORETICAL AND PRACTICAL ASPECTS OF USING TIME MANAGEMENT IN THE VOCATIONAL TRAINING OF FUTURE JUNIOR SPECIALISTS IN NURSING IN COLLEGES
}

Стаття присвячена узагальненню теоретичних розвідок, присвячених проблемі профресійної підготовки майбутніх молодших спеціалістів сестринської справи в коледжах. На основі аналізу літературних джерел встановлено, що наукові здобутки педагогів-новаторів створюють теоретичне підгрунтя для осучаснення освітнього середовища медичних закладів освіти, де здобувають квалісрікацію майбутні медичні сестри. Теоретично обірунтовано практичні аспекти навчання студентів медичних коледжів раціональних методів організації роботи з використанням тайм-менеджменту. Аргументовано, що управління часом (Time Management TМ) окреслює можливості майбутніх медичних сестер у таких напрямах: підвищувати ефективність роботи за допомогою самоменеджменту; навчитися чітко виокремлювати головне і першочергове в роботі; навчитися ефективно справлятися 3 несподіваними i терміновими справами, перевантаженнями і стресами; створювати оперативні й перспективні плани свого професійного й особистісного розвитку тощо. Узагальнено, що важливим чинником підвищення ефективності роботи сестринського персоналу $є$ навчання студентів усім видам тайм-менеджменту, починаючи з особистого.

3 метою опанування майбутніми молодшими спеціалістами сестринської справи основ тайм-менеджменту необхідно спрямовувати студентів на усвідомлення й виконання таких етапів, як: ідентиорікація профресійного завдання (проблеми, ситуації), неточне визначення якого може спричинити некомпетентні, помилкові, навіть шкідливі для здоров'я пацієнта дії; визначення цілей у вирішенні окресленого завдання й обґрунтування оптимальних професійних дій медичної сестри для його розв'язання; презентація альтернативних дій, допустимих у роботі медичної сестри; порівняння альтернатив і вибір кращої з позиції тайм-менеджменту на основі застосування методів математичної статистики; апробація альтернативних профресійних дій, щоби переконатися в досягненні бажаного результату і довести їхню доцільність у контексті оптимізації діяльності сестринського персоналу. Узагальнено, що адаптація основних положень тайм-менеджменту до організації навчання студентів у медичних коледжах сприятиме оптимізації процесу профресійної підготовки майбутніх молодших спеціалістів сестринської справи.

Ключові слова: студенти, медичний коледж, майбутні молодші спеціалісти сестринської справи, тайм-менеджмент.

The article deals with the generalization of theoretical investigations, devoted to the problem of vocational training of future junior specialists in nursing in colleges. Based on the analysis of literary sources, it has been determined that scientific achievements of teachers-innovators create theoretical background for modernization of educational environment of medical institutions of education, where future nurses acquire certain qualifications. It has been theoretically substantiated the practical aspects of students' study in medical colleges with rational methods of organizing work using Time Management (TM) describes possibilities of future nurses in the following directions: to increase the efficiency of work through self-management; to learn clearly distinguish the main and priority in work; to learn how to deal effectively with unexpected and urgent matters, overloads and stresses; to create operative and prospective plans of one's own professional and personal development, etc. It has been generalized that an important factor of increasing efficiency of nursing staff work is students' study, using all types of Time Management, starting with personal one.

In order to master by future junior specialists in nursing with Time Management basics is necessary to direct students to the awareness and realization of such stages: identification of professional task (problems, situations), inaccurate determination of which may lead to incompetent, erroneous, or even harmful to the patient's health actions; identification of goals in realization the determined task and substantiation of optimal professional actions of nurses for its solving; presentation of alternative actions, which are permissible in the work of a nurse; comparison of alternatives and choose of better position of TM on the basis of using methods of mathematical statistics; approbation of the alternative professional actions to make sure you achieve the desired result and prove their feasibility in the context of optimization of nursing staff activities. It has been generalized that adaptation of the basic provisions of Time Management to the organization of students' study in medical colleges will promote optimization of the process of vocational training of future junior specialists in nursing. Key words: students, medical college, future junior specialists in nursing, Time Management.
Постановка проблеми в загальному вигляді. Динамічні процеси, які супроводжують усі сорери розвитку сучасного суспільства, впливають і на розвиток, реорганізацію, стандартизацію, ресоормування системи охорони здоров'я. Очікування прогресивних змін у медицині не лише сфери стосуються надання висококваліфрікованої медичної допомоги пацієнтам, а й залежать від організаційних умов роботи лікувально-профрілактичних закладів охорони здоров'я, що в сукупності зале- 
жить від рівня профресійної компетентності, підготовленості, готовності фрахівців-медиків (лікарі, медичні сестри) до продуктивної роботи за фрахом.

Основну роль у підготовці майбутніх молодших спеціалістів сестринської справи виконують викладачі медичних коледжів. Наукові здобутки педагогів-новаторів створюють теоретичне підґрунтя для осучаснення й оновлення освітнього середовища медичних закладів освіти, де здобувають кваліфрікацію майбутні медичні сестри. Експериментальна перевірка дієвості окремих методів і педагогічних технологій, які використовуються в медичних коледжах, створює практичну базу для формування важливих професійних якостей майбутніх фрахівців сестринської справи. Отже, актуалізується проблема узагальнення теоретичних і практичних досягнень у контексті вдосконалення профресійної підготовки майбутніх молодших спеціалістів сестринської справи в коледжах.

Аналіз останніх досліджень і публікацій. Теоретичною основою для практичного вдосконалення професійної підготовки сучасних медичних сестер є наукові публікації, у яких дослідники простежують соціально-історичні тенденції становлення та розвитку медсестринства (С. Андрейчин, Ю. Лавриш, Г. Паласюк та ін.), розкривають особливості реформування сестринської освіти в Україні та світі (О. Варава, Х. Козак, І. Мельничук, М. Шегедин, С. Ястремська та ін.), визначають перспективні напрями професійної підготовки сестринського персоналу (Л. Мазур, І. Махновська, Н. Рега, О. Усинська й ін.) і аргументують структуру базової моделі медсестринства в Україні (3. Алтинбекова, В. Іванова, М. Шегедин [1]); презентують методику фрормування професійної ідентичності майбутніх молодших спеціалістів сестринської справи (О. Біда, А. Саблук [2]) та ін.

Виділення не вирішених раніше частин загальної проблеми. Серед значної кількості наукових розвідок, присвячених проблемі професійної підготовки медсестринських кадрів, є дослідження, у яких узагальнені історичні аспекти становлення медсестринства та навчання медичних сестер, охарактеризовано й експериментально перевірено інноваційні підходи до організації навчання в медичних коледжах тощо. Однак потребує поглибленого вивчення проблема підготовки молодших спеціалістів сестринської справи до практичної роботи з урахуванням основ тайм-менеджменту, що сприятиме більш чіткій організації навчання та профресійної діяльності сестринського персоналу.

Мета статті - теоретично обґрунтувати практичні аспекти навчання студентів медичних коледжів раціональних методів організації роботи за срахом із використанням тайм-менеджменту.

Виклад основного матеріалу. Ефективність профресійної діяльності фрахівців будь-якої спеціальності і кваліфікаційного рівня залежить не лише від рівня підготовленості, а й від особистісних якостей працівника. Однією з важливих ознак профресійної діяльності медичних сестер є вміння раціонально використовувати робочий час. Адже своєчасне і кваліфіковане надання необхідної медичної допомоги може бути тим важливим чинником, який врятує життя пацієнтам. Отже, навчити майбутніх молодших спеціалістів сестринської справи ефрективно керувати робочим часом - актуальна проблема. Дослідники зауважують, що не випадково управління часом (Time Management) найпопулярніша тема тренінгів у всьому світі останніми роками, і окреслюють можливості такої діяльності для фрахівця, який матиме змогу:

- підвищувати ефективність роботи за допомогою самоменеджменту;

- навчитися чітко виокремлювати головне і першочергове в роботі;

- навчитися ефективно справлятися 3 несподіваними і терміновими справами, перевантаженнями і стресами;

- створювати оперативні й перспективні плани свого професійного й особистісного розвитку;

- працювати, «виходячи 3 особистої місії, на основі своїх цінностей і принципів» [3, с. 7].

Коли говоримо про тайм-менеджмент у професійній діяльності майбутніх медичних сестер, маємо на увазі навчання студентів медичних коледжів управляти своєю діяльністю, оскільки керувати часом неможливо. Проте в терміні «таймменеджмент» уживається слово «час» (time), що підкреслює значущість оптимізації використання такого ресурсу в роботі за фрахом.

Економісти пропонують класифікувати таймменеджмент (далі - ТМ) таким чином: особистий, командний і корпоративний. Важливим чинником підвищення ефективності роботи сестринського персоналу $є$ навчання студентів усім видам ТМ, починаючи з особистого. Адже особисте зацікавлення медичної сестри в опануванні вмінь і навичок ТМ полягає в тому, щоб не імітувати бурхливу діяльність, а опанувати техніку особистої професійної ефективності в межах встановленого терміну (наприклад, у період 8-12-годинного чергування медичної сестри, або для ухвалення адекватного і відповідального рішення в екстрених ситуаціях надання необхідної медичної допомоги тощо).

Важливо сорормувати в майбутніх молодших спеціалістів сестринської справи здатність до відповідальних професійних рішень, що передбачає встановлення пріоритетності першочергових дій медичної сестри. Рішення $€$ однією 3 основних фрорм діяльності, спрямованої на досягнення цілей, і передбачає чітке фрормулювання цілей, визначення конкретних ефективних професійних дій і засобів досягнення. Тому дослідники зазначають: «Як правило, фрормулювання рішення містить 
констатуючу (інфрормація про стан вирішуваної проблеми) і результативну (розпорядження про дії) частини» [3, с. 13].

Якщо у процесі виконання профресійних фрункцій на робочому місці медичні сестри не завжди мають можливість проаналізувати й обґрунтувати доцільність виконання тих чи інших дій (особливо в екстрених випадках), то в період навчання студенти медичних коледжів набувають умінь і навичок успішної, раціональної й ефективної професійної діяльності. 3 метою опанування майбутніми молодшими спеціалістами сестринської справи основ ТМ необхідно спрямовувати студентів на усвідомлення й виконання таких етапів:

- ідентифрікація профресійного завдання (проблеми, ситуації), неточне визначення якого може спричинити некомпетентні, помилкові, навіть шкідливі для здоров'я пацієнта дії;

- визначення цілей у вирішенні окресленого завдання й обґрунтування оптимальних профресійних дій медичної сестри для його розв'язання;

- презентація альтернативних дій, допустимих у роботі медичної сестри;

- порівняння альтернатив і вибір кращої з позиції ТМ на основі застосування методів математичної статистики;

- апробація альтернативних профресійних дій, щоб переконатися в досягненні бажаного результату і довести їхню доцільність у контексті оптимізації діяльності сестринського персоналу.

У формуванні мотиваційної сфрери майбутніх молодших спеціалістів сестринської справи набуває особливої значущості встановлення цілей просресійної підготовки студентів у медичних коледжах. Це спонукає викладачів концентрувати увагу не на самому процесі навчання, а на тому, для чого відбувається оновлення й осучаснення усталеної методики викладання тих чи інших дисциплін. Таким чином і викладачами, і студентами окреслюється кінцевий результат профресійної підготовки майбутніх молодших спеціалістів сестринської справи, який може визначатися за допомогою чітко визначених критеріїв і показників сформованого френомену - готовності, підготовленості, професійної компетентності чи інших якостей чи властивостей випускників медичних коледжів.

Дослідники узагальнюють 10 основних принципів (вимог) постановки цілей: досяжність, гнучкість, вимірюваність, зорієнтованість у часі, визначеність у часі, конкретність, сумісність (несуперечливість), прийнятність (зокрема, й морально-етична), чітке формулювання, реалістичність [3, с. 80].

Процес визначення цілей охоплює три етапи:

1) встановлення мети (чого прагне студент: підвищити рівень успішності, розширити професійний світогляд і компетентність, отримати диплом, якомога швидше стати самостійною людиною і працювати за фрахом медичної сестри тощо);
2) ситуаційний аналіз (що майбутній молодший спеціаліст сестринської справи може зробити, щоб досягти окресленої цілі: поглиблено вивчати фахові дисципліни, займатися самоосвітою, активізувати практичну діяльність на заняттях чи в закладах охорони здоров'я тощо);

3) визначення покрокових дій для досягнення цілей, у результаті чого можуть виникати інші проміжні цілі.

Важливо, щоб у процесі визначення цілей i викладачі, і студенти не припускалися помилок, що можуть стати на заваді досягненню окресленої мети. Основні помилки в цілевиявленні такі:

- встановлення невідповідних цілей: інколи викладачами обирається ціль (наприклад, підвищення рівня компетентності майбутніх медичних сестер), проте у процесі організації навчання відбувається перетворення засобів досягнення цілі (використання нових педагогічних методів і технологій) на нову ціль - осучаснення освітнього процесу, що не завжди враховує попередньо окреслену мету. У студентів здобуття відповідної кваліфікації інколи втрачає свою цілевідповідність, а метою навчання в медичному коледжі стає отримання відмінних оцінок за знання теоретичного матеріалу, що не завжди може бути об'єктивним критерієм рівня професійної компетентності майбутнього фахівця чи його готовності до кваліфрікованої роботи за фрахом;

- встановлення недосяжних цілей, що спричинено реальними умовами освітнього середовища (матеріально-технічне й інформаційне забезпечення медичного коледжу), індивідуальними особливостями учасників освітнього процесу (педагогічна майстерність викладачів, рівень успішності студентів тощо);

- встановлення суперечливих цілей, наприклад, фрормування професійної компетентності майбутніх молодших спеціалістів сестринської справи (які працюватимуть у сучасних умовах реорормування галузі охорони здоров'я) не може відбуватися в усталеній системі традиційної підготовки студентів медичних коледжів, а потребує використання новихпедагогічнихтехнологій, сучасних досягнень у медичній і педагогічній сорерах.

Отже, учасники освітнього процесу покликані не лише визначати чіткі цілі своєї діяльності, а й враховувати перманентність такого процесу. Адже із часом виявляється, що деякі окреслені цілі вже досягнуті, тому виникає потреба визначити нові; окремі цілі можуть бути завищені або занижені, що потребує їх корекції.

У роботі зі студентами викладач спрямовує майбутніх медичних сестер на чітке визначення особистісних цілей, досягнення яких можна перевірити й оцінити як результат професійної підготовки в медичному коледжі. Доречно всі цілі згрупувати таким чином: 
- особисті цілі (у житті, навчанні);

- просресійні цілі (у майбутній кар'єрі);

- досвід, який можна набути у процесі професійної підготовки в медичному коледжі (досвід роботи за фрахом під час практики; комунікативний досвід безконорліктної міжособистісної взаємодії; уміння і навички самоосвітньої діяльності з метою підвищення профресійної компетентності тощо);

- перспективне планування особистісного зростання.

Важливим аспектом у тайм-менеджменті $€$ не лише спрямування студентів до самоаналізу 3 метою встановлення рівня професійних знань, умінь, досвіду, морально-етичних якостей, фрахових та інтелектуальних здібностей тощо, а й визначення засобів, з допомогою яких можна досягти окреслених цілей у професійному становленні майбутніх молодших спеціалістів сестринської справи. Науковці рекомендують здійснювати аналіз «ціль - засіб» і відображати його результати за такими ознаками: необхідні засоби (що потрібно?); здатності і засоби, що є в наявності; засоби, яких немає, але вони потрібні; практичні кроки для збільшення ресурсів [3, с. 85].

Після уточнення цілей і засобів доцільно встановити часові ресурси, обмеження, очікувані результати, що потребує чіткого планування роботи. Для цього було адаптовано для роботи викладачів медичного коледжу такі методики, які широко використовуються в підготовці майбутніх менеджерів: метод «Альпи» [3, с. 87]; планування за системою Б. Франліна [3, с. 92]; «пряме» плану- вання за допомогою картотек і щоденників обліку часу [3, с. 98] та ін.

Висновки. Удосконалення системи профресійної підготовки майбутніх молодших спеціалістів сестринської справи в медичних коледжах передбачає використання сучасних наукових підходів до організації освітнього процесу. Важливим чинником у такій справі є врахування можливостей оптимізації використання часових ресурсів викладачів і студентів. Доцільним є використання наукових здобутків з економічної сорери, де широко використовується технологія тайм-менеджменту. Адаптація основних положень тайм-менеджменту до організації навчання студентів у медичних коледжах сприятиме оптимізації процесу професійної підготовки майбутніх молодших спеціалістів сестринської справи.

Перспективи подальших наукових розвідок вбачаємо в розробленні методики використання тайм-менеджменту в підготовці майбутніх орахівців сестринської справи.

\section{БІБЛІОГРАФІЧНИЙ СПИСОК:}

1. Алтинбекова 3., Іванова В., Шегедин М. До питання про базову модель медсестринства в Україні. Медсестринство. 2008. № 2. С. 34-36.

2. Біда О., Саблук А. Формування професійної ідентичності майбутніх молодших спеціалістів сестринської справи. Педагогічний часопис Волині. 2018. № 4 (11). С. 139-143.

3. Скібіцька Л. Тайм-менеджмент : навчальний посібник для студентів економічних вузів. Київ : Кондор, 2009. 528 с. 